\title{
CONFLICT OF LAWS IN LATIN-AMERICAN COUNTRIES $^{1}$
}

\section{T. ESQUTVEL OBREGÓN \\ Of the Mexican Bar}

The sources of private international law are: the treaties between nations which create a positive rule binding the nations parties thereto; the rules established in the statutes of every country, which present the local law for the solution of such international conflicts; finally, science, which studies the general principles of law and seeks to create a common ideal for the solution of those conflicts.

In this study we shall confine ourselves to the rules established in the statutes of the Latin-American countries, ${ }^{2}$ and to present the conclusions arrived at by the South American Congress held in Montevideo in $1888-1889$.

The reader must not expect that all the points that may give rise to international conflicts are covered in this study. Perhaps his impression will be that the article is fragmentary, but this deficiency is due to the fact that the statutes do not always cover all the points. In some countries there are rules which are not found in others, and vice versa. He must not be disappointed, therefore, in finding that after the statement of certain rules, we mention only some of the codes of the Latin-American countries, omitting others which do not refer, so far as we have been able to find, to that particular matter. On the other hand, some rules referring to particular contracts or acts are not discussed here because they find their place in the corresponding chapter of my treatise on Latin-American law, whereas in the present article I usually refer to the general principles.

General remarks. All the rules which are herein set forth are subject to a superior principle, namely, that prohibitory laws concerning persons, their acts or property, and those which relate to public order or good morals, are not overruled by virtue of laws enacted or judgments rendered, or by regulations or agreements made in a foreign country.

\footnotetext{
2 The substance of this article will appear in a chapter in a forthcoming book on Latim-Americar Commercial Law by T. Esquivel Obregón, to be published and copyrighted by World Book Company, Yonkers-on-Hudson, New York.

* The modern Spanish codes will also be considered, not only because they have been the model of some American countries, but because they are now in force in Cuba and Porto Rico. It will be understood when we mention Spain, that Cuba and Porto Rico are included, unless otherwise stated.

- Spain, II c.c; Argentina, I4 c.c.; Brazil, I7 c.c; Honduras, 2372 c.c; and Mexico, 15 c.c. (c.c. is the abbreviation for civil code.)
} 
The party who invokes rights created by a foreign law has to prove the existence and the applicability of said law to the case."

As a consequence of the principle that contracts and acts are subject to the forms established by the law of the place where they are executed, the means of evidence are also governed by that law. Article 12 of the civil code of Brazil expressly so provides.

\section{STATUS AND CAPACITY OF PERSONS}

\section{A. In General}

System of Spain. Laws relating to family rights and obligations. or to the status, condition and legal capacity of persons, obligate citizens even though they reside in a foreign country.

System of Brazil. The same rule is established by article 8 of the civil code of Brazil; but article 9 provides that the law of the domicile is subsidiarily applied-

I. When a person has no nationality.

2. When dual citizenship is attributed to a person, namely that of his birth, and that of his parents, the Brazilian law governs, provided Brazilian citizenship be one of the two ascribed to the person.

System of Chile. The national law governs the status or legal capacity of a native, with respect to acts which must produce their effect in the country, and to the rights and obligations created through family relations only in matters referring to a native wife and children or relative. ${ }^{7}$

System of Mexico. According to article I2 of the civil code of the republic concerning the status and capacity of persons the Mexican law obligates Mexicans with respect to legal acts or con-

-Argentina 13 c.c.; Mexico 19 c.c-A decision rendered in this respect by the court of Medellin, in Colombia, on Sept 5, 1906, is very important, as it establishes that when the national law provides for the application of foreign laws, the judge must ex officio inquire into the provisions of said laws, if the parties have not done so. 2 Garavito A. Fernando, Jurisp. de los Triburales de Colombia, 725.

-Spain, 9 c.c. See In re Butler y Harrap Decision (Dec. 14, I901, no. 65, Tribunal Supremo, Cuba). Notwithstanding the fact that art. 1o of the civil code declares the rights of foreigners in Cuba, neither that provision nor any other gives jurisdiction to the Cuban Tribunals to gass upon them. 9 Jurisprudencia del Tributal Superior en materia civil (Havana, 1908) rorg. See also decisions of the Tribunal Superior, Spain, Dec. 11, 1893, and Dec. 18, 1894

See Hayti, 7 c.c.; Honduras, I3 c.c.; Santo Domingo, 3 c.c.; and Venezuela, 7 c.c.

- Pascuali v. Bicudo (Sept 25, 1914, Court of Appeals of S. Paulo, Brazil) 8 Rev. del Sup. Trib. Rio de Janeiro (IgI5) pt 2, p. 40.

'Chile, I5 c.c.; Colombia, Ig c.c.; Ecuador, I4 c.c.; Nicaragua, I5 c.c.; San Salvador, 15 c.c.; and Uruguay, 4 c.c. 
tracts which must be performed in Mexico, whatever the law of the country where the act or contract is executed. ${ }^{8}$

System of Costa-Rica. The civil code of Costa Rica embodies the same provisions as article 12 of Mexico, but adds that the Costa Rican law also binds aliens respecting acts which take place or contracts which are executed and must be performed in Costa Rica. ${ }^{2}$

The codes of the above-mentioned countries do not all provide for acts done by their citizens abroad, which must produce effect without their territory; this is a matter which has been left for the law of the country in which the act must take place, or to the agreement of the parties, or to the rules of international law, in default of both.

System of Argentina. The civil code of Argentina adopts an entirely different principle; instead of considering the law of the nationality of a person, in order to establish his status and legal capacity, it considers the law of the country in which a person is domiciled, independently of his nationality. This system is contained in the following articles:

Art. 6: "The capacity or incapacity of persons, domiciled in the territory of the republic, whether nationals or foreigners, is governed by the laws of this code, even though acts performed or property situated in a foreign country are involved."

Art. 7: "The capacity or incapacity of persons domiciled outside the territory of the republic is governed by the laws of their respective domiciles, even though acts performed or property situated in the republic are involved."

Art. 138: "Whoever moves his domicile from a foreign country to the territory of the republic, and is of legal age or has been emancipated according to the rules established in this code, shall be so considered even though he is a minor or not emancipated according to the laws of his former domicile."

\section{B. Citizenship and Domicile of Married Women}

With respect to the citizenship of a married woman, or her domicile, as the case may be, the Latin-American law is as divergent as it is in the matter of general status of persons. Therefore, we have to subdivide this point, in accordance with the different systems which prevail.

System of Spair. A married woman follows the status and citizenship of her busband in Spain and certain other countries. ${ }^{10}$

\footnotetext{
- Dorsay v. Diaz Barriga (Apr. I2, IgrI, Segunda Sala del Supremo Tribunal del Dist. Fed.) 23 Diario de Jurisprudencia (Mexico, 19II).

$40 \mathrm{cc}$

"Spain, 22 c.c; Bolivia, 8 c.c; Colombia, art 3, law of July 4, 1823; Guatemala, $56 \mathrm{ccc}$; Hayti, 5 pol $\mathrm{c}$ (pol c is the abbreviation for political constitution); Hondurss, $48 \mathrm{ccc}$; Peru, 41 c.c.; and Santo Domingo, I2 and Ig C.C.
} 
System of Mexico. The principle that a married woman follows the status and citizenship of her husband is true also of Mexico, ${ }^{12}$ Costa Rica, ${ }^{12}$ and Venezuela ;3 but matrimony does not denationalize a native woman when the law of the husband's home does not admit her to his citizenship. In the United States, under the act of March 2, I907, an American woman marrying a foreigner is denationalized whether or not by the law of her husband's country she acquires his nationality.

System of Brazil. In Brazil ${ }^{4}$ a system has been established which is virtually opposite to that heretofore described, inasmuch as it provides that a foreigner who possesses real estate in the republic and is married to a Brazilian woman, or has Brazilian children, is considered a Brazilian, provided he resides in Brazil; unless he expressly declares his intention of retaining his original citizenship. ${ }^{15}$

System of Ecuador. In Ecuador, a foreign woman married to an Ecuadorian acquires the citizenship of her husband, if she establishes a domicile in his country; and an Ecuadorian woman married in Ecuador to a foreigner does not lose her nationality as long as she remains domiciled in Ecuador. ${ }^{16}$

The laws of other Latin-American countries are silent upon this point, and since in principle it is necessary to have the consent of a person for acquiring, as well as for losing, his nationality, if the law does not provide otherwise, it seems to follow that in these countries marriage does not denationalize a native woman. ${ }^{\text {tr }}$

System of Argentina. It has been noted that in Argentina the principle of domicile has replaced that of nationality, and the law establishes in regard to the domicile the same rule that Spain has established in regard to the citizenship of married women. The Argentine civil code ${ }^{18}$ provides accordingly that a married woman who is separated by competent authority from her husband preserves the domicile of the latter unless she has created another for herself. The widow retains the domicile which her. husband had as long as she does not establish herself elsewhere. ${ }^{19}$

"Art 2, par. IV, law of May 28, 1886.

${ }^{23}$ Arts. 3 and 4, law of Dec. 21, 1886.

18 c.c.

"Art. 8, law no. 909, Nov. 12, 1902.

is See also Panama, 6 pol. c.; Uruguay, 8 pol. c. Cf. Octavio Rodrigo in 6 Revue de I'INSTTtut DE DroIt COMPARÉ, 307.

"Arts. I3 and 14, law of Aug. 28, 1886.

${ }^{17}$ I F. Laurent, Pristcipes de Droit Cizil Francais, no. 349.

${ }^{13}$ Art 90, sec IX.

10 A married woman during the existence of marriage takes the domicile and law of her husband: Luzato v. Arquato (Nov. 14, 1912, Camara Federal de Apelacion) Jurisprudencia de los Tribunales Naciomales (Nov. 1912) 93. 


\section{REAI ESTATE-GENERAI PRINCIPLE}

Real property is always governed by the law of the country in which it is situated. ${ }^{20}$

Spain, however, makes an exception to this rule in favor of legal and testamentary successions, as well as in regard to the order of succession, as to the amount of the inherited rights and to the intrinsic validity of the testamentary provisions, which are governed by the nationality of the decedent, whatever the nature of the property and the country in which it is located. ${ }^{21}$

The same exception is found in the civil code of Brazil, ${ }^{22}$ but it is limited to cases in which the decedent was not married to a Brazilian woman, or has not Brazilian children, because in these cases the succession is subject to the laws of Brazil.

On the other hand, in Hayti the law is so strict that not only does it provide that real property is governed by the lex rei sitae, but also that foreigners cannot acquire or possess it; thus when a Haytian gives up his citizenship he must part with any real property he may have in Hayti. ${ }^{28}$

\section{PERSONAL PROPERTY}

Traditional system. The tradition in the matter of personal property is that it is governed by the law of its owner. An ancient legal proverb states that movables adhere to the bones-meaning that movables are considered a part of the person himself.

Movables were formerly considered of no importance; only real property conveyed honor and consideration to its possessor. The law of each country, therefore, showed little interest in chattels, leaving them to be governed by the law of the person whether citizen or foreigner. An economic revolution later took place, and personal property is now as valuable as real estate; but the law reflects the tradition in Spain, where the civil code ${ }^{24}$ provides that personal property is subject to the law of the owner.

In countries such as France, where no provision is found, a doubt

* Spain, to c.c.; Argentina, to c.c.; Bolivia, 3 c.c; Brazil, Io c.c.; Chile, 16 c.c.; Colombia, 20 c.c.; Costa Rica, 4 c.c.; Ecuador, I5 c.c.; Guatemala, 5 c.c.; Hayti, 6 c.c; Honduras, 14 c.c.; Mexico, 13 c.c.; Nicaragua, 16 c.c.; Peru, 5 c.c.; San Salvador, 16 c.c; Santo Domingo, 3 c.c.; Uruguay, 5 c.c.; and Venezuela, 8 c.c.

Io c.c.

- Art 14

$=6$ pol. c. For further treatment of the capacity of foreigners to acquire real estate, see my treatise on Latin-American Commercial Law, ch: 3.

Art. Ia. 
may arise and opinion may be divided, but the weight of authority is for the application of the traditional principle. ${ }^{25}$

Argentine system. In reference to personal property, a distinction is made in Argentina, ${ }^{26}$ Brazil, ${ }^{27}$ and Uruguay ; ${ }^{28}$ when it has a permanent situs, it is governed by the law of the place where it is located; but personal property carried by its owner, or intended for his personal use, whether at his domicile or abroad, as well as personal property to be transported and sold, is governed by the law of the domicile of its owner.

Syistem of Chile. In Chile, ${ }^{29}$ Colombia, ${ }^{30}$ Costa Rica, ${ }^{31}$ Ecuador, ${ }^{32}$ Honduras, ${ }^{38}$ Nicaragua, ${ }^{34}$ and Venezuela, ${ }^{35}$ personal property as well as real property is governed by the law of the place where it is located.

\section{FORMS OF CONTRACTS AND LEGAT ACTS}

The legal formal requisites of contracts, wills and other instruments are governed by the law of the country in which they are executed..$^{36}$

In Costa Rica, ${ }^{37}$ Guatemala, ${ }^{38}$ Mexico, ${ }^{39}$ Panama, ${ }^{40}$ and Venezuela,, it is not compulsory to draw instruments according to the law of the place in which they are executed; the party may choose between the law of the country in which the instrument is made and that of the country in which it must have effect.

\footnotetext{
“Merlin, Répertoire, word "Loi," pr. 6, no. 3; F. Laurent, loc cit. vol. I, no. 120.

II c.c. " 4 c.c.

II c.c. 15 c.c.

5 c.c. 14 c.c.

$=16$ c.c. $16 \mathrm{c.c}$

${ }^{\infty} 20 \mathrm{ccc}$. $28 \mathrm{c.c}$.

"Spain, Ir c.c; Anglada de Serres v. Giro y Manzano (Dec. 8, 1902, no. 54 , Tribunal Supremo, Cuba). A last will made by a foreigner in Cuba must fulfill all the formalities of the Cuban laws, no matter what the provisions of the law of the foreigner's country. I4 Jurisp. del Trib. Sup. en mat. civil, 664

Argentina, 12 c.c; Bolivia, 36 c.c.; Brazil, II c.c.; Chile, 17 cc.; Colombia, 21 c.c.; Ecuador, I6 c.c.; Hayti (Mar. 23, 1829, court of cassation); Honduras, I5 c.c.; Nicaragua, I7 c.c.; and San Salvador, I7 c.c.

" $8 \mathrm{ccc}$.

I3 c.c.

- 4 c.c. Dorsay v. Diaz Barriga (Aṕr. 12, I9Ir, Segunda Sala del Trib. Sup. del Dist. Fed. Mexico). A foreign document written in a foreign language and presented without translation cannot be accepted. Diario de Jurisp. (IgrI).

Vega Perez v. Agente del Ministerio Público and Juez del Registro civil (June 26, I9ri, Segunda Sala del Trib. Sup. del Dist. Fed. Mexico): A religious marriage entered into in a foreign country in which the same is valid, produces all its effects in Mexico. Documents proceeding from a foreign country when duly authenticated constitute full evidence Ibid. Igrr. Convreur y Compañia v. Lack (Oct. 30, 1909) Ig Ibid. 729.

$\rightarrow$ c.

$9 \mathrm{cc}$
} 
The codes of Spain ${ }^{42}$ and Bolivia ${ }^{43}$ provide that when the aforesaid instruments are to be authenticated by diplomatic or consular officials of those countries abroad, the formalities required by the respective law of Spain or Bolivia must be observed.

Colombia, ${ }^{44}$ Costa Rica, ${ }^{45}$ Ecuador, ${ }^{46}$ Honduras, ${ }^{47}$ Nicaragua, ${ }^{48}$ San Salvador, ${ }^{19}$ and Venezuela ${ }^{50}$ have another limitation upon the above rule concerning the formal requisites of instruments, which provides that in case the codes or laws of said countries require the public instrument as evidence in matters within the jurisdiction of national courts, private instruments are invalid no matter what force they have in the country in which they were executed.

Argentina, ${ }^{51}$ Nicaragua $^{52}$ and San Salvador ${ }^{53}$ also limit the general principle by providing that contracts concluded in a foreign country conveying rights in real estate situated in the republic have the same force as those made within the state, provided they are executed in a public instrument and are presented legalized. Where the title of real property is sought to be conveyed to them, such conveyance is without effect unless the contract is protocolized by a decree of a judge of competent jurisdiction.

In treating below of wills we shall consider certain provisions referring to legal forms.

\section{EFFECTS OF CONTRACTS}

Argentina ${ }^{54}$ provides that contracts entered into in the republic or out of it, to be performed within its territory, are governed as to their validity, nature and obligation by the laws of the republic whether the contracting parties be nationals or foreigners. Contracts entered into in the republic to be performed outside of it are governed as to their validity, nature and obligation by the laws and usages of the country in which they are to be performed, whether the contracting parties be nationals or foreigners.

In Brazil ${ }^{55}$ the obligations are governed as to the substance and effects they produce by the law of the place where they were contracted. But the law of Brazil governs:

I. Contracts entered into in a foreign country which must be performed in Brazil.

2. Obligations contracted between Brazilians in foreign countries.

\begin{tabular}{|c|c|}
\hline 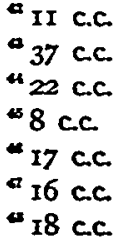 & 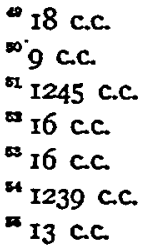 \\
\hline
\end{tabular}


3. Acts relative to real estate situated in Brazil.

4. Acts relative to the Brazilian mortgage system.

In Chile, ${ }^{58}$ Colombia, ${ }^{57}$ Guatemala, ${ }^{58}$ Honduras, ${ }^{50}$ Mexico, ${ }^{, 0}$ Peru, ${ }^{, 1}$ and San Salvador, ${ }^{82}$ the effects of contracts made in a foreign country, to be performed in the aforesaid countries, are governed by the law of those respective countries.

Peru ${ }^{63}$ provides that an obligation contracted between foreigners cannot be enforced in that country unless they have submitted themselves to the jurisdiction of the Peruvian courts.

The Costa Rican civil code provides that ${ }^{\text {s4 }}$

"In interpreting a contract and in determining its immediate and remote effects, the law of the place where it was made shall be taken into consideration; but if the contracting parties have the same citizenship their national law must prevail."

\section{WILIS}

We have already seen that in most of the Latin-American countries the legal formal requisites of wills are governed by the law of the country in which they are executed; but this general rule suffers some exceptions which we are going to review.

In Argentina, ${ }^{65}$ Chile, ${ }^{60}$ Colombia, ${ }^{67}$ Honduras, ${ }^{68}$ San Salvador, ${ }^{60}$ Nicaragua, ${ }^{70}$ Panama, ${ }^{71}$ and Uruguay, ${ }^{72}$ it is provided that a written will made by a citizen in a foreign country must be executed by a minister plenipotentiary of his government, a chargé d'affaires or a consul and two witnesses domiciled in the place where the will is made, and bearing the seal of the legation or consulate. When it is not executed before a head of legation, it must be viséed by the latter, if there is a head of legation, at the end thereof in an open will, and on the wrapper in a sealed one. An open will must always be rubricated by the head of legation, at the beginning and end of each page, or by the consul if there is no legation. If there be neither consulate nor

$\begin{array}{ll} & \text { I6 c.c. } \\ & 20 \text { c.c. }\end{array}$

" 16 c.c. See Dorsay v. Diaz Barriga (Apr. 12, I9Ir, Segunda Sala del Trib. Sup. del Dist. Fed. Mexico). If the obligations created in a foreign country are to be fulfilled in Mexico they must be governed by the Mexican laws: Cutelli de Contri v. Contri (Feb. I, Ig09, Segunda Sala del Trib. Sup. del Dist. Fed. Mexico) 23 Diario de Jurisp. (1900) I54. Peru, II56, I157 c.p.; Uruguay, 512, 513 c.p. ; and Venezuela, 722 cp.

of 40 c.c.

I6 c.c.

43 C.C.

4 c.c.

3670-3672 cc.

* I027-roza ce $\pi$ I053, I084, 1086 c.c.

rorr, ror2, rors c.c.

- ro58-1060 c.c.

io 127-129 c.c.

$\pi 767-769$ c.c.

728,829 c.c. 
legation of his country, these formalities must be fulfilled by the minister or consul of a friendly nation. The head of legation or the consul must forward a copy of the open will, or of the inscription on the wrapper of the sealed one, to the minister of foreign affairs of the country that he represents, and the minister, after authenticating the signature of the head of legation or consul, must transmit it to the judge of the last domicile of the deceased, in order that the judge may cause it to be incorporated in the protocols of the notary public of the same domicile. When the domicile of the testator in the country is unknown, the minister of foreign relations must forward the will to the judge of first instance of the capital for incorporation in the protocol of said notary as the judge may determine.

In Argentina, Chile, Colombia and Honduras, the will of a person who is outside of the respective country produces effect within it only if made with the formalities prescribed by the law of the place in which he resides, or according to those observed in the nation to which he belongs, or according to those which the national law prescribes.

According to the code of Brazilis legal or testamentary successions, the order of succeeding, the rights of the heirs and the intrinsic validity of a will are governed by the law of the country of the deceased, whatever the nature of the property and the country in which he is, except as otherwise provided by the Brazilian law in regard to vacant inheritances. If the testator was married to a Brazilian woman or if he left Brazilian children the rights of inheritance are governed by Brazilian law.

The Brazilian consular agents may serve as officers in the execution and approval of wills made by Brazilians in foreign countries, of serving the prescriptions of the Brazilian code.

The Chilean code $e^{74}$ and the Colombian code $e^{78}$ provide in the matter of inheritances that foreigners are called to the legal successions in Chile or Colombia, in the same manner and according to the same rules as the citizens of those countries. In the legal succession of a foreigner who dies within or without the territory of those republics, citizens must have as hereditary or conjugal portion or as alimony the same rights which belong to them according to the Chilean and Colombia law upon the legal succession of a Chilean or a Colombian. Citizens interested in a succession of that kind may ask for the application of property belonging to the deceased, within the territory of the country, up to the amount that may belong to them in the succession of the foreigner. The same rule is applied when the case

$14 \mathrm{cc}$

"997, 998 ce.

- I052, ros3 ce 
may give to the succession of a citizen of those countries who leaves an estate in a foreign country.

In Guatemala the civil code ${ }^{78}$ provides that in regard to legal formalities and wills, the laws of the countries in which they are executed must prevail. Natives or foreigners residing outside the territory of the republic may, however, comply with the legal formalities provided for by the law of Guatemala in cases in which the will must be complied with in that republic.

The rights and obligations arising from wills executed in a foreign country by citizens of Guatemala are governed by the law of Guatemala in all that must take effect in the republic.

In regard to the essential requisites of a will, the testator may choose between his national law and that of Guatemala, when the testament must be executed in the territory of the latter and the testament refers to personal property. As to real estate situated in Guatemala the laws of the republic must be observed.

According to the code of Hayti ${ }^{77}$ and the code of Santo Domingo, ${ }^{73}$ citizens of those republics who are in a foreign country may draw their wills in a private document, written, dated and signed in their own handwriting, or in a public instrument with the formalities established in the country in which they are.

Testaments made in a foreign country cannot be executed so far as they refer to property situated in those republics, except after being filed in the registry at the domicile of the testator, or if that be unknown, in the registry at his last known domicile. In case the testament contains provisions relating to real property situated in those republics, it must also be filed in the office of the place in which it is situated.

The code of Mexico ${ }^{29}$ provides that the Mexican law governs real property whether owned by citizens or foreigners, and that foreigners have no capacity to inherit either by will or by legal succession when, according to the laws of their countries, Mexicans are not permitted to receive legal or testamentary inheritances. ${ }^{80}$

The code of $\mathrm{Peru}^{8 \mathrm{x}}$ prescribes that foreigners residing in that country can devise to other foreigners the real property that they possess in their own country, or bequeath personal property, jewelry, money or merchandise which they have in the territory of Peru, according to their national law. But in disposing of the real property located in Peru, they are subject to the laws of Peru.

$\begin{array}{ll}\pi \text { I3-I5 c.c. } & \text { i3 c.c. } \\ \pi 805,806 \text { c.c. } & \$ 3300 \text { c.c. } \\ \pi 999,1000 \text { c.c. } & \approx 475 \text { c.c. }\end{array}$




\section{FOREIGN JUDGMENTS}

\section{Procedure}

It is a general principle that final judgments rendered in foreign countries have in the territory of a nation that force provided for in the respective treaties with those countries. ${ }^{82}$

Some nations, accepting the principle of reciprocity as a basis, prescribe that when there are no special treaties with a foreign nation in which the judgment was rendered, the judgment shall have the same force that is given in that nation to final judgments of the country in which it is to be enforced. If it is rendered in a country under whose laws judgments rendered in the other nation are not executed, the judgment is not enforceable in the latter. ${ }^{83}$

The following conditions must be satisfied before a foreign judgment may be enforced:

r. That it is final, and that it was rendered in a personal action.

2. That it is not a judgment by default.

3. That the obligation for the enforcement of which the action was instituted was lawful according to the laws of the country in which the request is made for its execution.

4. That the letter rogatory possesses the formal requisites which are necessary for its validity as evidence in the country in which it was issued and in the country in which its enforcement is requested.84

* Spain, 951 c.c.; Argentina, 558 c.p.; Bolivia, 7 c.c.; Chile, 239 c.p.; Colombia, 876 cp.; Cuba and Porto Rico, 950 c.p.; Ecuador, 235 c.p.; Guatemala, 1563 c.p.; Honduras, 235 c.p.; Mexico, 780 c.p.; Peru, II55 c.p.; San Salvador, 450 c.p.; and Uruguay, 511 c.p.

"Spain, 952, 953 c.p. A decision by the courts of Argentina, In re Bueno v. Rojal Insurance Co. (Aug. 5, I912) stated that judgments of foreign courts have no extraterritorial effect. Rev. de Leg. y Jurip. de la Rep. Argentina (I914) 568.

Chile, 240, 24I c.p.; Colombia, 876, 877 c.p. Judgments of foreign courts shall be without force in Colombia. unless a treaty otherwise provides. See Medellin (Aug. 2, 1906) 378; Garavito, Jurisp. de los Tribs. de Colombia; In re Echeverria (Jan. II, 1900, no. 5, Tribunal Superior, Cuba). See also 4 Jurisp. del Trib. Sup. en materia civil (1908) ro, and the case of In re Anglada de Serres v. Giro y Manzano (no. 54).

In this matter of proving foreign laws in Colombia, the provision of article 13. law no. 124, 1890, is also important. It reads as follows:

"Powers of attorney, acts referring to the civil status of persons and other documents executed in foreign countries, which the interested parties may produce before the courts and tribunals of Colombia, in order to prove their claims, shall be considered valid if they have been authenticated according to the Colombia laws. After they have been so authenticated, they are presumed to have been executed in conformity with the law of the place of their origin, unless the adverse party presents proof to the contrary."

* Spain, 954 c.p.; Argentina, 559 c.p.; Colombia, 878 c.p.; Costa Rica, 1067 c.p.; Cuba and Porto Rico, 953 c.p.; Ecuador, 500 c.p.; Guatemala, 1566 c.p.; Honduras, 238 cp.; Mexico, 785 c.p. See Cutelli de Contri v. Contri, note 60, 
Chile prescribes that when a foreign judgment is to be enforced there by reason of a special treaty or through reciprocity, the judgment shall have in the territory of Chile the same force which the decisions of Chilean courts have in the country in which the judgment was rendered, provided it has the following requisites:

I. That it does not conflict with the laws of the republic.

2. That it does not encroach upon the national jurisdiction.

3. That it is not a judgment by default.

4. That it has been declared enforceable by the laws of the country in which it was rendered.

In Peru the code of civil procedure prescribes, in matter of foreign judgment or decrees, as follows:

Art. II59: "In order that a foreign judgment be declared enforceable by the superior courts of the country it is required: that it shall not pass upon matters pertaining to the jurisdiction of the Peruvian courts, as set forth in the following article; that it is not contrary to good customs or to prohibitory laws of the republic; that it has the character of a final and enforceable judgment in accordance with the laws of the country in which the action was brought; and that the judgment debtor be served with process in the manner prescribed by the laws of the place."

Art. I160: "Peruvian courts have exclusive jurisdiction in cases relating to the following matters:

"I. Real estate located in the territory of the republic.

"2. Vessels under the Peruvian flag.

"3. Civil actions arising out of crimes, quasi-crimes, or negligence which occurred in Peru.

"4. Inheritances of Peruvians or of foreigners domiciled in Peru, whenever citizens of or foreigners residing in Peru or a Peruvian charitable institution or the state of Peru have an interest in the estate." 85

supra. In order to execute a foreign judgment in Mexico it is necessary that the judgment has been rendered in a personal action.

The action of divorce is not a personal action: Diario Jurisp. loc. cit; San Salvador, 451 c.p.; Uruguay, 514 c.p.

s In this connection, Colombia has an important provision relating to the manner in which the legality of a judgment must be proved, which is often a difficult matter. Art 879, c.p. reads :

"The force and legality of a judgment rendered in a foreign country are proved by means of a certificate from the diplomatic or consular agent of Colombia or of a friendly nation residing in the aforesaid country. This certificate must state:

"I. That the judgment was rendered in accordance with the laws of that country.

"2. That according to said laws, the judgment debtor has exhausted his legal remedies.

"Should there be no diplomatic or consular agent of Colombia or of any other friendly nation in the country in which the judgment was rendered, the certificate referred to in this article may be obtained from the secretary of state of said country, through the Minister of Foreign Affairs of Columbia." 
VIII. INTERNATIONAL CONGRESS OF MONTEVIDEO

One of the most notable events in the history of Latin-American private international law was the meeting of the South American International Congress in Montevideo during the years 1888 and I889. At that Congress the following countries were represented: Argentina, Bolivia, Brazil, Chile, Paraguay, Peru and Uruguay.

Eight treaties were drafted on the following matters: International civil law, legal procedure, copyright, international commercial law, international criminal law, the liberal professions, patents and trade marks, and an additional protocol..$^{56}$

Brazil and Chile did not accept those treaties. The main reason for their refusal was that in their law they follow the rule derived from the principle of nationality for solving the conflicts of law, whereas the treaties accept the principle of domicile.

Dr. Andrade Figueiras, representative of Brazil, in opposing the acceptance of the Montevideo treaties on the ground of their acceptance of the principle of domicile instead of that of nationality, summarized his objection thus:

"The law of the domicile for governing the relations whether of citizens or foreigners, means a retrogression in the evolutionary progress of our science, and is almost the derogation of the principles which constitute the basis of private international law.

"The economic interest of the new countries in itself makes the adoption of the law of nationality advisable for the solution of questions relating to the status and civil capacity of foreigners, and for their succession."

The same representative considered the principle of domicile, far from protecting new countries, as an obstacie to the attraction of capital and to the settlement of immigrants; this principle aims to break the relations of the immigrants with the country of origin.

Among the rules established in the treaty on international civil law, the following are worth noticing:

Art. I. The capacity of persons is governed by the law of their domicile.

Art. 2. A change of domicile cannot alter the capacity already acquired as a result of emancipation, legal majority or judicial declaration of competency.

Art. 5. The law of the place where a person resides determines the conditions necessary to constitute a domicile.

Art 6. Parents, guardians and curators ${ }^{87}$ have their domicile in the territory of the state from whose laws they derive their functions.

- These treaties were ratified by the Argentine Congress on December 6, 1894; by the Congress of Peru on October 25, 1889; by that of Paraguay on September 10, 1889, and by that of Bolivia on February 25, 1904

- A curator is a person appointed to supervise the acts of the guardian. 
Art 8. The domicile of husband and wife is where the legal partnership of marriage has been established, and in default thereof it is presumed to be that of the husband. A woman judicially separated from her husband retains his domicile so long as she does not establish another.

Art. 9. Persons not having a known domicile are considered as domiciled in the place of their residence.

Art. 13. The law of the matrimonial domicile governs:

(a.) The separation of husband and wife.

(b.) Their divorce, provided the reason alleged therefor is admitted by the law of the place in which the marriage took place.

Art. 26. Property, whatever its nature, is governed exclusively by the law of its situs, in matters relating to its character, possession, and alienation, absolute or relative, and to all the legal relations, real in character, of which it is capable.

Art. 29. Debts are considered as situated in the place in which the corresponding obligations are to be performed.

Art. 3o. A change in the location of property does not affect rights acquired in accordance with the law of the place where it was at the time of the acquisition. The interested persons, however, are bound to fulfill the formal and substantial requisites necessary by the law of the place of the new location in order to acquire or preserve the aforesaid rights.

Art. 3I. Rights acquired by third parties in such property according to the law of its new location, after the change has been made, prevail over those of the first owner.

Art. 33. The same law governs their creation, nature, validity, effects, consequences and performance: in short, all matters of whatever nature concerning contracts.

Art. 34. It follows that contracts relating to certain and specific things are governed by the law of the place where such things are at the time of the execution of the contract.

Those relating to things determined only by their class, by the law of the domicile of the obligor at the time of entering into the contract.

Those relating to fungible things, by the law of the domicile of the debtor at the time of the agreement.

Those dealing with the performance of services:

(a.) If they refer to things, by the law of the place where they were at the time of the execution of the contract.

(b.) If their efficacy is related to some special place, by that in which there are to produce their effect.

(c.) In other cases, by that of the domicile of the debtor at the time the agreement was entered into.

Art 35. A contract for the sale of goods in different places where 
conflicting laws prevail is governed by the domicile of the contracting parties, should it be common at the time of the agreement; otherwise by the law of the place in which the contract was entered into, should their domicile be different.

Art. 36. Accessory contracts are governed by the law of the principal obligation to which they refer.

Art. 37. The final conclusion of contracts entered into by means of correspondence or agents is governed by the law of the place whence the offer started.

Art. 39. The form of public instruments is governed by the law of the place where they are executed.

Art. 5I. Negative prescription of personal actions is controlled by the law to which the obligations out of which they arose are subject.

Art. 52. Negative prescription of real actions is governed by the law of the place where the burdened property is situated.

Art. 53. If the burdened property is chattel and its location has been changed, prescription is governed by the law of the place where the necessary period of prescription has been completed.

Art. 54. Acquisitive prescription of chattels or of realty is governed by the law of the place in which the property is situated.

In the convention relating to legal procedure we find the following rules:

Art. I. Actions at law and their incidents, whatever their character, shall be presented in accordance with the law of the nation in which they are instituted.

Art. 2. Evidence shall be admitted and evaluated or righted according to the law governing the subject-matter of the action. From this rule is excepted such evidence as is not authorized by the law of the place in which the action is proceeding.

Art. 3. Judgments of courts and decisions of arbitrators duly confirmed, rendered in civil or commercial cases; public instruments, and those issued by officers of the state, which have been authenticated and letters rogatory or requisitorial shall be given effect by each of the high contracting parties according to the stipulations of this treaty, provided they are properly legalized.

Art. 4. A legalization is considered properly made when it takes place according to the law of the country where the document originated. provided it has been authenticated by the diplomatic or consular agent of the country in which its enforcement is asked. This consular agent must reside in the place where the document is legalized.

Art. 5. Judgments or decisions by arbitrators and acts of noncontentious jurisdiction issued in civil or commercial matters in one of the countries which is a party to this agreement, shall have the same force in the territory of the others that they have in the issuing country, provided they possess the following requisites: 
(a.) That the judgment was rendered by a court which is competent in the international acceptance of that word.

(b.) That it had the character of a final judgment, considered as res judicata in the country in which it was rendered.

(c.) That the party against whom it was rendered was legally summoned and represented in the suit or else that he was declared to be in default in accordance with the laws of the country where the action was instituted.

(d.) That it is not contrary to the public policy of the country in which it is to be executed.

Art. 6. In requesting the enforcement of a judgment the following documents shall be required:

(a.) A complete copy of the judgment or arbitrator's decision.

(b.) A copy of all the papers necessary to prove that the parties were cited.

(c.) An authenticated copy of the judicial decree in which it is declared that the judgment or arbitrator's decision has the character of a final judgment and has been established as res judicata, as well as a copy of the laws upon which said decree is based.

Art. 7. The character of executive or compulsory judgments or arbitrator's decisions and the proceedings which must be followed in order to execute them shall be determined by the law of procedure of the country in which execution is demanded.

Art. 8. Matters falling within noncontentious jurisdiction, such as inventories, opening of last wills, appraisements or other acts of like nature performed in one state shall have in the other contracting states the same force and effect as if they had been performed in their own territory, provided they have the requisites established in the previous articles.

Art. 9. Letters requisitorial or rogatory whose object it is to serve legal notices, to receive testimony of witnesses or to perform any other judicial act, must be complied with in any of the contracting countries, when such letters have all the requirements exacted by this treaty.

Art. ro. When the letters requisitorial or rogatory refer to attachment of property, appraisements, inventories or provisional remedies, the judges shall do everything necessary respecting the appointment of experts, appraisers, depositories; - $i$. e., everything that may lead to the best fulfillment of the commission.

Art. II. Letters requisitorial or rogatory shall be carried out in accordance with the laws of the country in which the execution is requested.

Art. 12. Persons interested in the execution of letters requisitorial or rogatory may at their expense appoint attorneys. 